\section{Kidney Blood Pressure Research}

\title{
The Protective Effect of Propofol Against Ischemia-Reperfusion Injury in the Interlobar Arteries: Reduction of Abnormal Cx43 Expression as a Possible Mechanism
}

\author{
Yue-Chen Chang ${ }^{a}$ Wen-Jing Xue $e^{a, b} \quad$ Wei Jia Yang Wang ${ }^{a, c, e} \quad$ Yan-Ping Wang ${ }^{d}$ \\ Wen-Yan Shi ${ }^{a, c}$ Li-Ya Shan ${ }^{a, c}$ Liang Zhang ${ }^{a, c}$ Chao-Yang Tan ${ }^{a}$ Ke-Tao Ma ${ }^{a, c}$ \\ Li Lia,c Jun-Qiang Si ${ }^{a, c, e, f}$
}

aDepartment of Physiology, Shihezi University Medical College, Shihezi, 'bepartment of Anesthesiology, Xi'an No.4 Hospital, Xi'an, 'The key Laboratory of Xinjiang Endemic and Ethnic Diseases, Shihezi University Medical College, Shihezi, dHoubo College, Xinjiang Medical University, Karamay, Xinjiang, eDepartment of Physiology, Wuhan University School of Basic Medical Sciences, Wuhan, fDepartment of Physiology, Huazhong University of Science and Technology of Basic Medical Sciences Wuhan, China

\section{Key Words}

Propofol • Ischemia reperfusion injury • Connexin $43 \cdot$ Gap junction • Renal vasoconstrictor response

\begin{abstract}
Background/Aims: This experimental study aims to observe whether the protective effect of propofol against renal ischemia-reperfusion injury (IRI) in the rat interlobar artery occurs through altered expression of the gap junction protein connexin 43 (Cx43). Methods: This study randomly divided male Sprague Dawley (SD) rats into an untreated control group, a sham-operated control group (sham group), an ischemia-reperfusion group (IR group), a propofol group (propofol+IR group) and a fat emulsion group (Intralipid group). The ischemia/ reperfusion model was prepared through resection of the right kidney and noninvasive arterial occlusion of the left kidney. Forty-five minutes after renal ischemia-reperfusion, an automatic biochemical analyzer was employed to measure blood urea nitrogen (BUN) and serum creatinine $(\mathrm{SCr})$; changes in renal tissue pathology were observed using hematoxylin and eosin $(\mathrm{HE})$ staining, and the vasomotor activity of the interlobar artery was detected using a pressure mechanogram technique. The protein expression of $\mathrm{Cx} 43$ in renal artery cross-sections was determined through western blotting. Results: The experimental study confirmed that the $\mathrm{BUN}$ and $\mathrm{SCr}$ of rats markedly increased after ischemia-reperfusion injury; additionally, we observed some coagulation necrosis and shedding of cells, some solidification of nuclear chromatin, degeneration of cytoplasmic vacuoles, high renal interstitial vascular congestion

Y.-C. Chang, W.-J. Xue and W. Ji contributed equally to this work.

\begin{tabular}{ll}
\hline Professor Jun-Qiang Si & Department of Physiology, Shihezi University Medical College, 59 Beier Road \\
and Li Li & Shihezi, Xinjiang 832002 (P.R. China) \\
& E-Mail sijunqiang@shzu.edu.cn; lily7588@163.com
\end{tabular}
\end{abstract}




\section{Kidney Blood Pressure Research}

Kidney Blood Press Res 2018;43:1607-1622

DOI: $10.1159 / 000494450$

Published online: 22 October 2018

(C) 2018 The Author(s). Published by S. Karger AG, Base

www.karger.com/kbr

and obvious inflammatory cell infiltration, characterized by focal hemorrhages. Furthermore, the contraction activity of the renal interlobar artery greatly decreased, and the tension of the arteries in the renal lobe increased remarkably. After the gap junction blocking agents 2-APB and Gap27 were applied, the systolic velocity of blood vessels and the vascular contraction rate both decreased. In addition, the expression of $\mathrm{Cx} 43$ in kidney tissues increased markedly. The damage was more severe after $24 \mathrm{~h}$ of ischemic reperfusion than after only $4 \mathrm{~h}$. However, after pretreatment with propofol, regardless of whether ischemia-reperfusion was applied for $4 \mathrm{~h}$ or $24 \mathrm{~h}$, the previously increased expression of $\mathrm{Cx} 43$ decreased obviously, and all forms of renal damage were reversed. Conclusion: Our research suggests new ways for propofol to relieve ischemia-reperfusion injury by decreasing the abnormal expression of the gap junction protein $\mathrm{Cx} 43$. This study reveals a novel mechanism for the action of propofol against IRI, and we hope this finding will lead to new treatments for IRI.

(C) 2018 The Author(s)

Published by S. Karger AG, Basel

\section{Introduction}

Reperfusion after ischemia can restore the function of the tissue or organ, repair the structural damage and allow the patient to recover in most cases. Sometimes, however, reperfusion not only fails to restore the function of tissues and organs but also aggravates their dysfunction and structural damage after ischemia. This phenomenon of irreversible damage is known as ischemia-reperfusion injury (abbreviated as IRI) [1]. Increased free radicals, intracellular calcium overload, the opening of the mitochondrial permeability transition pore, endothelial dysfunction, the presence of a prothrombogenic phenotype, the development of capillary no-reflow, and pronounced inflammatory responses also play major roles in the development of reperfusion injury [2-4]. Renal IRI is a very sophisticated pathophysiological phenomenon, and its mechanism remains somewhat unclear.

A gap junction (GJ) is a type of special connection channel generally existing in cells. These junctions are critical for the transmission of electrical and biochemical signals between cells [5]. Studies have suggested that GJs exist not only in renal vascular endothelial cells and smooth muscle cells but also in other renal tissue cells. In addition, GJs are critical for renal circulation [6, 7]. However, there has been little research into whether the expression of gap junction proteins is altered in renal IRI. In particular, gap junction 43 (Cx43) is present in almost all tissue. Intact endothelial cells are essential for the maintenance of normal physiological function in normal vascular tissue, and $\mathrm{Cx} 43$ is critical for the maintenance of endothelial continuity and integrity [8].

Propofol is commonly used as an anesthetic. In recent years, studies have demonstrated the protective effects of propofol against ischemic injury in the kidneys, liver and heart [911]. It has been suggested in early studies that propofol protects against opioid-induced hyperresponsiveness of airway smooth muscle during target-controlled infusion anesthesia [12]. Propofol relieves renal oxidative injury and contributes to repair when administered during IRI, and the anesthetic may exert a protective effect by regulating bone morphogenetic protein 2 expression in renal IRI [13]. Some studies have identified that IRI increases the production of the lipid peroxidation by-product malondialdehyde (MDA) in wholekidney homogenates. In contrast, propofol pretreatment decreases MDA levels, increases superoxide dismutase (SOD) levels and improves renal dysfunction when administered during IRI. For example, rats pretreated with propofol are protected from kidney dysfunction and histological damage. Protection is associated with a decrease in proinflammatory cytokine generation and a concomitant increase in BMP2 expression [13]. Additionally, propofol pretreatment can relieve IR damage in LLC PKl cells by activating $\mathrm{K}_{\text {ATP }}$ channels [14]. Another study suggests that the microvascular injury occurs during renal ischemiareperfusion injury and that propofol can protect against oxidation, improve the inhibition of intestinal injury and inflammation, and protect the permeability of capillaries [15]. It is believed that the protective effect of propofol on the kidney may be due to preconditioning 


\section{Kidney Blood Pressure Research}

Kidney Blood Press Res 2018;43:1607-1622

\begin{tabular}{l|l}
\hline DOI: $10.1159 / 000494450$ & (c) 2018 The Author(s). Published by S. Karger AG, Base
\end{tabular}

Published online: 22 October 2018

www.karger.com/kbr

of cell or tissue protective mechanisms such as HO-1 or heat shock protein [16] or may act on the $\mathrm{K}_{\text {АтP }}$ ion pathway in the kidney [14]. The latter played a role in fighting oxygen free radicals, inflammation and apoptosis pathway and played a role in alleviating renal cell and tissue damage. The study suggested that propofol pretreatment might alleviate hypoxia reoxygenation injury by stimulating p38/MAPK [17]. Propofol can not only reduce renal ischemia-reperfusion injury but also adjust GJ function to reduce acute renal injury in orthotopic liver transplantation $[13,18]$. However, it is not clear what part propofol plays in protection against renal IRI. It is necessary to further study whether propofol is associated with expressional changes and functional regulation of gap junction proteins.

This study began by generating a kidney ischemia-reperfusion model in rats and comparing the changes in contraction in the renal interlobar artery before and after ischemia-reperfusion. Additionally, the regulatory effects of propofol on arterial contraction and gap junction (Cx43) expression during renal IRI were examined. The aim of this study was to explore the protective effect of propofol against kidney IRI and the mechanism of the effect, providing new insights for the future clinical treatment of IRI.

\section{Materials and Methods}

\section{Drugs and reagents}

The materials purchased were as follows: anti-Cx43 monoclonal antibody from Abcam (UK), national drug approval No. ab170190; peroxidase-Conjugated AffiniPure goat anti-rabbit IgG from ZSGB-BIO (China), national drug approval No. ZB-2301; anti- $\beta$-actin monoclonal antibody from ZSGB-BIO (China), national drug approval No. TA-09; peroxidase-conjugated AffiniPure goat anti-mouse IgG from ZSGB-BIO (China), national drug approval No. ZB-2305; propofol, fat emulsion, phenylephrine and acetylcholine from Sigma, USA; 2-aminoethyl diphenylborinate (2-APB) from Sigma, USA, approval No. 047K1192; ketamine from Gutian Fujian Pharmaceutical Co., Ltd. (Fujian, China), national drug approval No. H35020148; VITROS Chemistry Products CREA Slides from Ortho-Clinical Diagnostics, Inc. (China), national drug approval No. YZB/USA 0073-2015; VITROS Chemistry Products BUN/UREA Slides from Ortho-Clinical Diagnostics, Inc. (China), national drug approval No. 20152402807; acetylcholine chloride from Sigma, USA, approval No. A2661; phenylephrine hydrochloride from Sigma, USA, national drug approval No. PHR1017.

\section{Animals}

One hundred adult male SD rats (body weight, 240-260 g) were provided by the Animal Center of Xinjiang Medical University (Urumqi, China). The use of animals in the present study was approved by the Committee of Animal Experimental Ethics of The First Affiliated Hospital of Medical College, Shihezi University (Shihezi, China) (animal use certificate No. SCXK Xin 2003-0001). The animals were singly housed in cages in a specific-pathogen-free environment at $22 \pm 1^{\circ} \mathrm{C}$ with a relative humidity of $40-70 \%$ under a $12 \mathrm{~h} / 12 \mathrm{~h}$ light/dark cycle and provided with food and water ad libitum. All protocols were approved by the Institutional Animal Care and Use Committee (IACUC) at the Medical College of Shihezi University and complied with the Guidelines for the Care and Use of Laboratory Animals published by the US National Institutes of Health [19].

\section{The establishment of a rat renal IRI model}

All rats were fasted for $12 \mathrm{~h}$ and anesthetized with $10 \%$ chloral hydrate $(0.04 \mathrm{~g} / \mathrm{kg})$. The left renal artery was isolated and occluded with a noninvasive microvascular clamp. The vascular clamp was released after reperfusion. In the sham operation group, silk sutures were passed under the left renal artery but not tied. In the renal ischemia-reperfusion (IR) group, the left kidney was subjected to ischemia for $45 \mathrm{~min}$, followed by reperfusion for $4 \mathrm{~h}$ or $24 \mathrm{~h}$. In the propofol+IR group, the rats received propofol $(50 \mathrm{mg} / \mathrm{kg})$ by intraperitoneal injection once daily for three days before being subjected to $45 \mathrm{~min}$ of kidney ischemia and $4 \mathrm{~h}$ of reperfusion. The drug doses of propofol and the administration method were derived from the literature [20-22]. The fat emulsion group was treated in the same manner as the propofol group, except that the fat emulsion Intralipid was injected instead of propofol. 


\section{Kidney Blood Pressure Research}

Kidney Blood Press Res 2018;43:1607-1622

\begin{tabular}{l|l}
\hline DOI: $10.1159 / 000494450$ & (c) 2018 The Author(s). Published by S. Karger AG, Base
\end{tabular}

Published online: 22 October 2018

www.karger.com/kbr

Experimental groups and protocol

One hundred male SD rats were randomly divided into ten groups as follows: propofol intervention (Pro $50 \mathrm{mg} / \mathrm{kg}$ ) $4 \mathrm{~h}$ and $24 \mathrm{~h}$; fat emulsion (Intralipid $50 \mathrm{mg} / \mathrm{kg}$ ) $4 \mathrm{~h}$ and $24 \mathrm{~h}$; renal ischemia-reperfusion (IR) $4 \mathrm{~h}$ and $24 \mathrm{~h}$; sham operation (Sham) $4 \mathrm{~h}$ and $24 \mathrm{~h}$; and blank control (Control) $4 \mathrm{~h}$ and $24 \mathrm{~h}$. Each group contained 10 rats. After $4 \mathrm{~h}$ or $24 \mathrm{~h}$ of reperfusion, the rats were reanesthetized with the same dose of $10 \%$ chloral hydrate; their abdomens were opened, and $5 \mathrm{ml}$ of blood was drawn from the abdominal aorta. Plasma samples were immediately transferred to a biochemistry laboratory and stored in a refrigerator (DW-86L626; Haier Special Electric Appliance Co., Ltd, Qingdao, China) at $-80^{\circ} \mathrm{C}$ to measure BUN and SCr. Then, the rats' left kidneys were quickly removed and placed in a $4^{\circ} \mathrm{C}$ oxygen-saturated $\left(95 \% \mathrm{O}_{2}\right.$ and $\left.5 \% \mathrm{CO}_{2}\right)$ saline solution. The kidneys were cut in the longitudinal direction and fixed on a silica gel petri dish. The interlobar arteries were exposed, and the perivascular connective tissue was removed under a dissecting microscope. A 2 to $3 \mathrm{~mm}$ segment of each renal interlobar artery was cut for a stress electromyogram detection. The other part of the blood vessel was used for the measurement of protein expression.

\section{Measurement of BUN and SCr levels}

BUN and SCr levels were measured using a Roche automatic biochemical analyzer (Modular DPP-H7600; First Affiliated Hospital of Shihezi University Laboratory, China). The results of both measurements were recorded in $\mathrm{mg} / \mathrm{dl}$.

\section{Histopathological examination}

The blood vessels from the different groups of rats were collected and immediately washed twice with phosphate-buffered saline. Then, the vessels were modified and fixed in $10 \%$ neutral formalin. The samples were successively dehydrated and embedded in paraffin. Tissue sections $(4 \mu \mathrm{m})$ were fixed in ethanol at ambient temperature, stained with hematoxylin and eosin (HE), and photographed under a light microscopy (automatic biochemical analyzer, Olympus).

\section{Preparation of renal interlobar arterial segments in rats of each group}

The literature [13] was referenced for the preparation of interlobar arterial segments and the technique of Stress electromyogram. Rats were anesthetized by intraperitoneal injection of $10 \%$ chloral hydrate $(0.04 \mathrm{~g} / \mathrm{kg})$. The kidneys were quickly removed and placed in a $4^{\circ} \mathrm{C}$ oxygen-saturated $\left(95 \% \mathrm{O}_{2}\right.$ and $5 \% \mathrm{CO}_{2}$ ) saline solution (physiological salt solution, PSS). The kidneys were cut longitudinally and fixed on a silica gel petri dish. The interlobar arteries were exposed, and the perivascular connective tissue was removed using a dissecting microscope. The arteries were cut into 2 to $3 \mathrm{~mm}$ sections for pressure-induced myotome experiments.

Detecting the change in vessel diameter using a pressure myograph system

The arterial segments were placed in a perfusion vessel containing $5 \mathrm{ml}$ of PSS and were cannulated at both ends with glass micropipettes (1.2 mm; World Precision Instruments, LLC, Sarasota, FL, USA), which were stretched to a diameter of 300 to $400 \mu \mathrm{m}$ diameter for the MRA and protected using an 11-0 nylon monofilament suture. The glass micropipettes were shaped with a P-97 puller (Sutter Instrument, Novato, CA, USA). To reinforce the vessel and prevent leaks, a syringe containing PSS liquid was used to slowly wash away the residual blood in the lumen, which was drained through the glass micropipette fixed to the other end of the vessel. The perfusion tank was moved to the stage of an inverted microscope at $100 \times$ magnification. The blood vessels were submerged in PSS liquid at $37^{\circ} \mathrm{C}$ and $100 \%$ oxygen saturation. The baths were aerated with $95 \% \mathrm{O}_{2}$ and $5 \% \mathrm{CO}_{2}$ at a constant rate. Vascular segments were standardized after reaching equilibrium. KPSS solution $(\mathrm{KCl} 60 \mathrm{mmol} / \mathrm{L})$ was used to stimulate vascular contraction. The vessels were washed with PSS and incubated for $30 \mathrm{~min}$; then, PE $\left(10^{-5} \mathrm{~mol} / \mathrm{L}\right)$ was administered. ACh $\left(10^{-5} \mathrm{~mol} / \mathrm{L}\right)$ was used to relax the blood vessels when the vasoconstriction plateaued. If the diastolic rate was above $80 \%$, the endothelium would be considered intact, suggesting that the vascular activity was suitable for the experiment. To continuously record the outer diameter of the isolated vascular segments, we transferred the vessel and the perfusion chamber to an inverted trinocular microscope with an analog video camera and a computer-assisted image capture system (Pressure Myograph System; Danish Myo Technology A/S, 


\section{Kidney Blood Pressure Research}

Kidney Blood Press Res 2018;43:1607-1622

\begin{tabular}{l|l}
\hline DOI: $10.1159 / 000494450$ & (c) 2018 The Author(s). Published by S. Karger AG, Base
\end{tabular}

Published online: 22 October 2018

www.karger.com/kbr

Aarhus, Denmark) [14] once the tissues were mounted. Pressure type arterial measuring instrument (DMT, 110P, Denmark).

The experiment was initiated after $30 \mathrm{~min}$ of stabilization. The intra-arterial pressure was maintained at $7.98 \mathrm{kPa}$; the temperature was controlled at $37^{\circ} \mathrm{C}$; the PSS water bath was controlled at a volume of $5 \mathrm{ml}$, and $60 \mathrm{mmol} / \mathrm{L} \mathrm{KCl}$ was added for vascular stability. Then, PSS was added until the maximum blood vessel stability was reached, followed by $60 \mathrm{mmol} / \mathrm{L} \mathrm{KCl}$, and the process was repeated for three cycles; changes in diameter were observed when the blood vessels were in the stable state. The variable of interest was the vessel diameter; changes in this variable were calculated as $\mathrm{D}(\mathrm{m})=\mathrm{Dp}-\mathrm{Dk}(\mathrm{Dp}$ : diameter of vascular segment stabilized in PSS; Dk: diameter of vessel after stabilization in $60 \mathrm{mmol} / \mathrm{L} \mathrm{KCl);} \mathrm{to} \mathrm{reduce} \mathrm{the} \mathrm{differential} \mathrm{error}$ caused by different vessel diameters, we calculated the vascular shrinkage as a percentage of diameter: $(\%)=(\mathrm{Dp}-\mathrm{Dk}) / \mathrm{Dp}) \times 100 \%[23,24]$.

\section{Detection of Cx43 protein expression in the renal artery by western blotting}

Total protein was extracted from the renal artery using lysis buffer, and the protein concentration was determined using the BSA method. Equal amounts of renal artery homogenates $(25 \mathrm{mg} / \mathrm{lane})$ were separated by $10 \%$ SDS-PAGE and transferred to a $0.2-\mathrm{mm}$ nitrocellulose membrane. The nitrocellulose blots were blocked by incubation in TBST (10 mM Tris- $\mathrm{HCl}, \mathrm{pH} 7.5,150 \mathrm{mM} \mathrm{NaCl}, 0.1 \%$ TWEEN 20) containing $5 \%$ milk for $1 \mathrm{~h}$. Next, the samples were mixed with anti-CX43 polyclonal antibody (1:1000 dilution)/ $\beta$ actin polyclonal antibody $(1: 20000)$ and kept at $4^{\circ} \mathrm{C}$ overnight. Afterwards, the blots were washed in TBST five times for $15 \mathrm{~min}$. The blots were incubated with horseradish peroxidase-linked anti-rabbit IgG for $1 \mathrm{~h}$ at ambient temperature and then washed five times in TBST for $15 \mathrm{~min}$. A chemiluminescent peroxidase substrate was applied in line with the manufacturer's instructions, and the membranes were exposed briefly to X-ray film. Protein expression was examined using an imaging software program (EN61000-6-1; Bio-Rad Laboratories, Inc., 1000 Alfred Nobel Drive, Hercules, California 94547, USA)[22].

\section{Statistical analysis}

Experimental data were presented as the mean \pm standard error of the mean. SPSS 17.0 software processing (SPSS, Inc., Chicago, IL, USA) was applied for statistical analysis. Variables that followed the normal distribution were compared among different groups by one-way analysis of variance, and those that did not follow the normal distribution were compared by the rank-sum test; enumeration data were analyzed by the chi-squared test. $\mathrm{P}<0.05$ was considered statistically significant.

\section{Results}

\section{Changes in BUN and SCr in each group}

Renal IR can result in abnormal increases in serum BUN and SCr, and renal function is often assessed by measuring BUN and SCr [25]. Propofol markedly reduced the levels of BUN and SCr. The serum levels of BUN and SCr increased by a dramatic 4- to 6-fold after IR ( $\mathrm{n}=10$, $\mathrm{P}<0.05$ or $\mathrm{P}<0.01)$ and was reduced by propofol pretreatment $(\mathrm{n}=10, \mathrm{P}<0.05$ or $\mathrm{P}<0.01)$ (Table 1). As the results suggest, propofol may attenuate IR-induced renal damage. There was no difference between the sham operation group and the control group, and there was no difference between the Intralipid group (receiving only the fat solvent used to dissolve propofol) and the IR group.

\section{Pathological changes in rat kidneys under light microscopy}

The glomeruli and renal tubules did not show significant morphological changes between the control group and the sham group at $4 \mathrm{~h}$ or $24 \mathrm{~h}$ (Fig. 1). However, the renal tubules were damaged $4 \mathrm{~h}$ after renal ischemia-reperfusion, with the proximal tubule being the most severely damaged. The clarity of the tubular structures was reduced, and the lumen was dilated. Tubular cells and exfoliated cells were observed in the tubular epithelium. Some cells that had undergone coagulation necrosis were being shed, and some of the nuclear chromatin was subject to cytoplasmic vacuolar degeneration; renal interstitial hypervascular hyperemia 


\section{Kidney Bloód Pressure Research}

Chang et al.: The Protective Effect of Propofol Against Ischemia-Reperfusion Injury in

the Interlobar Arteries

with inflammatory cell infiltration was significant, showing a focal hemorrhage area. Renal IRI and the accompanying damage were more severe in the $24 \mathrm{~h}$ group than in the $4 \mathrm{~h}$ group. Both the extent and the degree of renal tubular injury were markedly lower in the propofol+IR group than in the IR group. In the former group, the nuclei were normal, and the tubules showed only a small amount of tubule-type interstitial hyperemia, with the bleeding obviously reduced. The effects of Intralipid were similar to those of renal IRI (not shown in Fig. 1, 4 h). The method of Paller et al. was employed to calculate the pathological score of the renal tissue [26], specifically, the pathological score of $\mathrm{HE}$ staining of the renal tissue from the rats of each group, and the data are presented as the mean \pm standard error (Table 2).

\section{Intergroup differences in the diameter of the renal interlobar artery}

By fixing the renal interlobar artery of rats in a pressure myograph system, we measured the initial average diameter of the blood vessels. The mean diameter of all blood vessels was $448.76 \pm 61.43 \mu \mathrm{m}(\mathrm{n}=60)$, while the group means for the sham, IR and propofol+IR groups were $468.45 \pm 23.24$ $\mu \mathrm{m}(\mathrm{n}=20), 396.37 \pm 16.75 \mu \mathrm{m} \quad(\mathrm{n}=20)$, and $457.45 \pm 24.76 \mu \mathrm{m}(\mathrm{n}=20)$, respectively. When $60 \mathrm{mmol} / \mathrm{L} \mathrm{KCl}$ was used to induce renal interlobar artery vasoconstriction, the blood vessels contracted, decreasing in average diameter. The vascular diameter decreased to an average of $120.13 \pm 9.67 \mu \mathrm{m}(\mathrm{n}=30)$, and the mean diameters of the blood vessels of the sham group, IR group and propofol+IR group decreased to $73.51 \pm 9.28 \mu \mathrm{m}(\mathrm{n}=10), 175.47 \pm 13.32$
Table 2. Pathological score of HE staining of renal tissue from rats of each group (mean $\pm S D, n=10$ ). Compared with sham group: ${ }^{*} \mathrm{P}<0.05,{ }^{*} \mathrm{P}<0.01$, compared with I/R group: ${ }^{\#} \mathrm{P}<0.05,{ }^{\# \#} \mathrm{P}<0.01$, compared with Pro group: ${ }^{\Delta} \mathrm{P}<0.05,{ }^{\Delta \Delta} \mathrm{P}<0.01$

\begin{tabular}{lcc}
\hline \multirow{2}{*}{ Group } & \multicolumn{2}{c}{ Pathological score } \\
& $4 \mathrm{~h}$ & $24 \mathrm{~h}$ \\
\hline Control group & $7.18 \pm 1.68$ & $7.11 \pm 1.24$ \\
Sham group & $6.96 \pm 1.65$ & $7.02 \pm 1.17$ \\
I/R group & $20.90 \pm 10.31^{*}$ & $49.75 \pm 16.37^{* *}$ \\
Propofol+I/R group & $11.62 \pm 2.56^{* \#}$ & $29.83 \pm 12.15^{* \# \#}$ \\
Intralipid group & $21.58 \pm 9.6^{*} \Delta$ & $41.63 \pm 13.65^{* * \Delta \Delta}$ \\
\hline
\end{tabular}




\section{Kidney \\ Blood Pressure \\ Research}

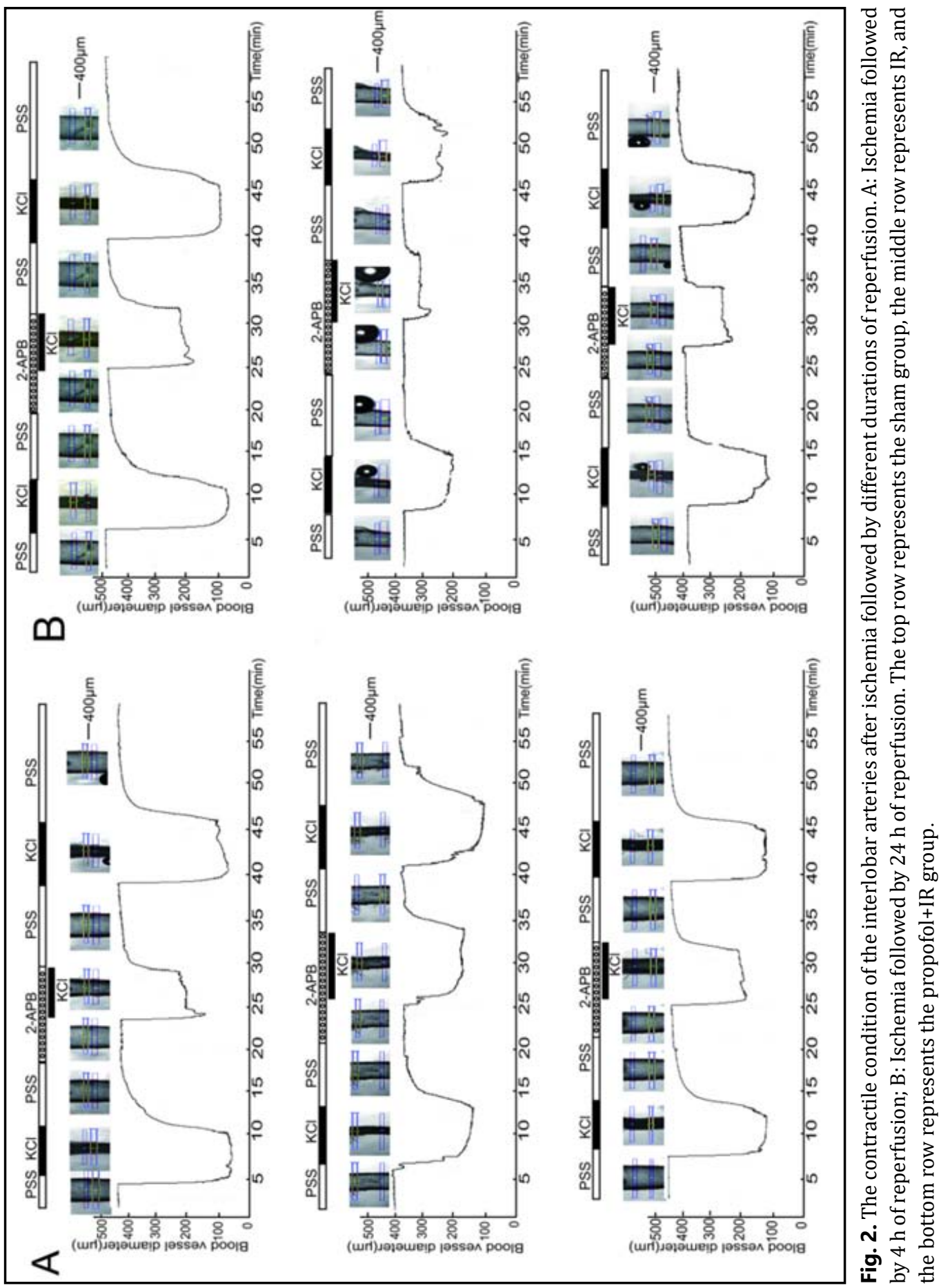

$\mu \mathrm{m}(\mathrm{n}=10)$ and $116.37 \pm 11.36 \mu \mathrm{m}(\mathrm{n}=10)$, respectively, when reperfusion lasted $4 \mathrm{~h}$. After 4 $\mathrm{h}$ of reperfusion, the vascular diameter decreased to an average of $136.33 \pm 10.21 \mu \mathrm{m}(\mathrm{n}=30)$, and the mean diameters of the blood vessels of the sham group, IR group and propofol+IR group decreased to $69.13 \pm 10.34 \mu \mathrm{m}(\mathrm{n}=10), 208.65 \pm 11.46 \mu \mathrm{m}(\mathrm{n}=10)$ and $132.43 \pm 9.91 \mu \mathrm{m}$ $(\mathrm{n}=10)$, respectively (Fig. 2).

Theinterlobar arteries of the IRgroup were markedly smaller in initialdiameter than those of the sham group $(n=20, p<0.05)$, and propofol+IR noticeably restored the initial diameter of the arteries, as shown in Fig. 3. The effect of high $\mathrm{KCl}(60 \mathrm{mmol} / \mathrm{L})$ on vasoconstriction 


\section{Kidney \\ Blood Pressure Research}

Kidney Blood Press Res 2018;43:1607-1622

\begin{tabular}{l|l}
\hline DOI: $10.1159 / 000494450$ & (c) 2018 The Author(s). Published by S. Karger AG, Basel
\end{tabular}

Published online: 22 October 2018 www.karger.com/kbr

1614

was obviously weaker than that of the sham treatment, and 24 $h$ of reperfusion $(n=10, p<0.01)$ was obviously weaker than $4 \mathrm{~h}$ $(\mathrm{n}=10, \mathrm{p}<0.05)$. However, whether reperfusion lasted $4 \mathrm{~h}$ or $24 \mathrm{~h}$, the arterial vasoconstriction induced by $60 \mathrm{mmol} / \mathrm{L} \mathrm{KCl}$ propofol+IR group slightly restored constriction capability.

Changes in the amplitude and velocity of renal interlobar artery constriction induced by high $\mathrm{KCl}$ in each group

The rate of change of vascular contraction amplitude in response to high potassium, $(\%)=((\mathrm{Dp}-\mathrm{Dk}) /$ Dp) $\times 100 \%$, was calculated for each experimental group. For the sham, IR and propofol+IR groups after 4 $\mathrm{h}$ of reperfusion, the contraction rate values were $86.37 \pm 11.12 \%$ $(\mathrm{n}=10), 65.21 \pm 13.43 \%(\mathrm{n}=10)$ and $74.56 \pm 10.14 \%(\mathrm{n}=10)$, respectively. The rates of shrinkage after $24 \mathrm{~h}$ of reperfusion were $85.67 \pm 9.84 \%$ $(\mathrm{n}=10), 47.36 \pm 8.97 \%(\mathrm{n}=10)$ and $71.05 \pm 11.33 \%(n=10)$, respectively, for the sham, IR and propofol+IR groups, as calculated with the abovementioned formula.

The rate of change of vasoconstriction caused by high potassium was markedly lower after ischemia and $4 \mathrm{~h}$ or $24 \mathrm{~h}$ of reperfusion, with or without propofol pretreatment, than in the sham operation group, as shown in Fig. 4. In addition, the decrease in the rate of change of vasoconstriction was more obvious after $24 \mathrm{~h}$ of reperfusion than after only $4 \mathrm{~h}$. The results also suggested that propofol could, to some extent,

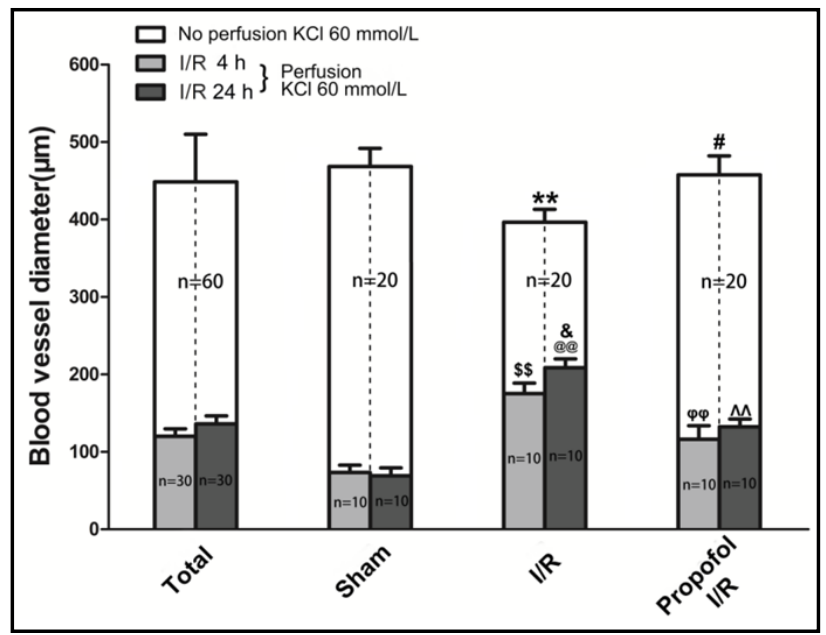

Fig. 3. Differences in arterial diameter under different conditions. ${ }^{* *} \mathrm{P}<0.01$ vs sham group (no perfusion with 60 $\mathrm{mmol} / \mathrm{L} \mathrm{KCl}$; ${ }^{\#} \mathrm{P}<0.05$ vs IR group (no perfusion with 60 $\mathrm{mmol} / \mathrm{L} \mathrm{KCl);}{ }^{\$ \$} \mathrm{P}<0.01$ vs sham group, $4 \mathrm{~h}$ (perfusion with 60 $\mathrm{mmol} / \mathrm{L} \mathrm{KCl}$ ); $@ \mathrm{P}<0.01$ vs sham group, $24 \mathrm{~h}$ (perfusion with $60 \mathrm{mmol} / \mathrm{L} \mathrm{KCl}$ ); ${ }^{\psi} \psi \mathrm{P}<0.01$ vs IR group, $4 \mathrm{~h}$ (perfusion with 60 $\mathrm{mmol} / \mathrm{L} \mathrm{KCl}$ ); ${ }^{\wedge} \mathrm{P}<0.01$ vs IR group, $24 \mathrm{~h}$ (perfusion with 60 $\mathrm{mmol} / \mathrm{L} \mathrm{KCl}$ ); ${ }^{\circledR} \mathrm{P}<0.05$ vs sham group, $24 \mathrm{~h}$ (perfusion with $60 \mathrm{mmol} / \mathrm{L} \mathrm{KCl}$.

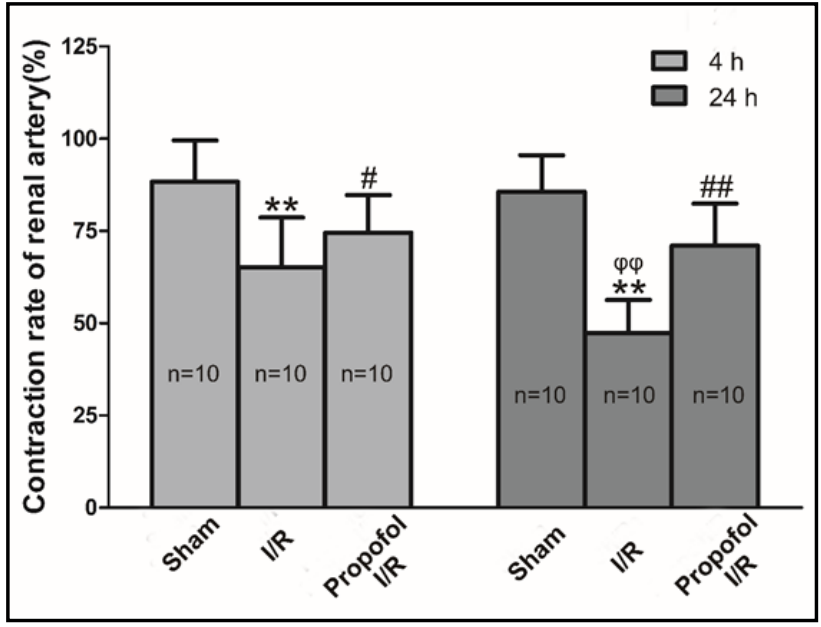

Fig. 4. The rate of change of vascular contraction amplitude of the interlobar artery in response to high $\mathrm{KCl}$ in different groups. ${ }^{* *} \mathrm{P}<0.01$ vs sham group; ${ }^{\#} \mathrm{P}<0.05$ or ${ }^{\# \#} \mathrm{P}<0.01$ vs IR group; ${ }^{\psi \psi} \mathrm{P}<0.01$ vs IR group for $4 \mathrm{~h}$. correct the decrease in the rate of vasoconstriction induced by ischemia-reperfusion.

The systolic velocity of each experimental group was also examined to measure the change in blood vessel constriction rate in the interlobar arteries after ischemia-reperfusion. The systolic velocities of blood vessels in the sham, IR and propofol+IR groups at $4 \mathrm{~h}$ were $3.82 \pm 0.44 \mu \mathrm{m} / \mathrm{s}(\mathrm{n}=10), 2.17 \pm 0.54 \mu \mathrm{m} / \mathrm{s}(\mathrm{n}=10)$ and $3.21 \pm 0.41 \mu \mathrm{m} / \mathrm{s}(\mathrm{n}=10)$, respectively. The values for the same groups at $24 \mathrm{~h}$ were $3.67 \pm 0.51 \mu \mathrm{m} / \mathrm{s}(\mathrm{n}=10), 1.25 \pm 0.42 \mu \mathrm{m} / \mathrm{s}(\mathrm{n}=10)$ and $2.34 \pm 0.63 \mu \mathrm{m} / \mathrm{s}(\mathrm{n}=10)$, respectively. 


\section{Kidney Blood Pressure Research}

Kidney Blood Press Res 2018;43:1607-1622

\begin{tabular}{l|l}
\hline DOI: $10.1159 / 000494450$ & (c) 2018 The Author(s). Published by S. Karger AG, Basel
\end{tabular}
The systolic velocity of the renal interlobar artery caused by high potassium after $4 \mathrm{~h}$ or 24 $\mathrm{h}$ of reperfusion was obviously slower than that of the sham operation group, as shown in Fig. 5. In addition, the decrease in the systolic velocity of the renal interlobar artery was more obvious after $24 \mathrm{~h}$ of reperfusion than after only $4 \mathrm{~h}$. The results also suggested that propofol could correct the slowing of the systolic velocity of the renal interlobar artery induced by ischemia-reperfusion.

The effect of 2-APB on the amplitude and velocity of the renal interlobar artery constriction induced by high $\mathrm{KCl}$ in each group

2-APB has several pharmacological functions, including the nonspecific blocking of gap junction communication. Without application of 2-APB, the ischemia-reperfusion $4 \mathrm{~h}$ groups (sham, IR and propofol+IR groups) had contraction rate values of $86.37 \pm 11.12 \% \quad(n=10)$, $65.21 \pm 13.43 \% \quad(\mathrm{n}=10) \quad$ and $74.56 \pm 10.14 \%(\mathrm{n}=10)$, respectively, after the rat renal interlobar artery was treated with $\mathrm{KCl}(60$ $\mathrm{mmol} / \mathrm{L}$ ). After $24 \mathrm{~h}$ of reperfusion, the sham, IR and propofol+IR group had contraction rates of $85.67 \pm 9.84 \%(\mathrm{n}=10), 47.36 \pm 8.97 \%$ $(n=10)$ and $71.05 \pm 11.33 \%(n=10)$, respectively. With application of 2-APB (100 mmol/L), the shrinking rates of the sham $4 \mathrm{~h}$ group, the IR $4 \mathrm{~h}$ group and the propofol $4 \mathrm{~h}$ group were $66.67 \pm 12.21 \%$ $(\mathrm{n}=10), 52.78 \pm 13.37 \%(\mathrm{n}=10)$ and $63.04 \pm 1179 \%(\mathrm{n}=10)$, respectively.

The shrinking rates of the sham $24 \mathrm{~h}$ group, the IR $24 \mathrm{~h}$ group and the propofol $24 \mathrm{~h}$ group were $64.14 \pm 10.16 \%(n=10), 30.56 \pm 9.87 \%(n=10)$ and $42.5 \pm 10.58 \%(n=10)$, respectively.

Each group had a significantly lower shrinkage rate after incubation with 2-APB (100 $\mathrm{mmol} / \mathrm{L})$ than without 2-APB treatment $(\mathrm{n}=10, \mathrm{p}<0.01)$ (Fig. 6). After incubation with 2-APB $(100 \mathrm{mmol} / \mathrm{L})$, the renal interlobar artery shrinkage rate of the IR group treated with high $\mathrm{KCl}$ decreased in comparison with that of the sham group, and the difference was statistically significant at $4 \mathrm{~h}(\mathrm{n}=10, \mathrm{P}<0.05)$ and $24 \mathrm{~h}(\mathrm{n}=10, \mathrm{P}<0.01)$; the renal interlobar artery

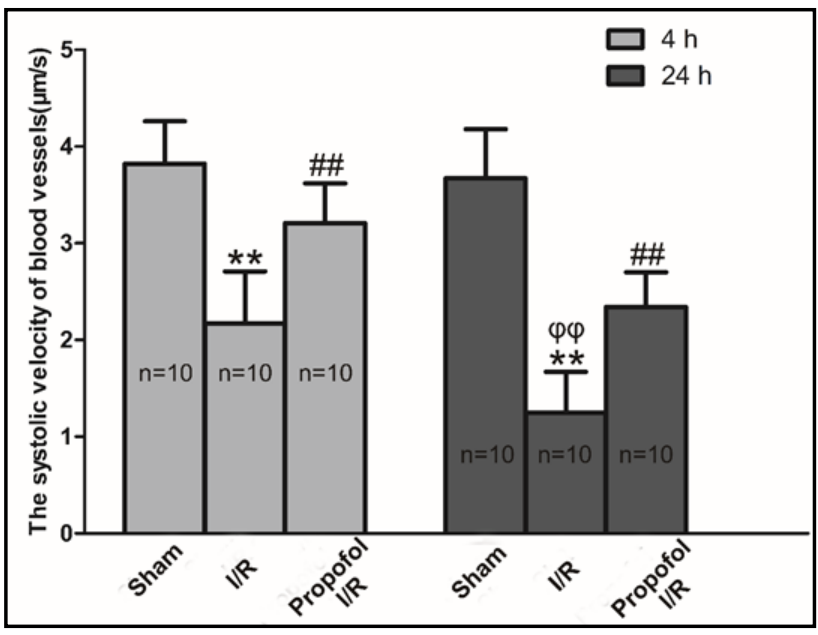

Fig. 5. Changes in the vascular systolic velocity of the renal interlobar artery in different groups in response to high $\mathrm{KCl}$. ${ }^{* *} \mathrm{P}<0.01$ vs sham group; ${ }^{\# \#} \mathrm{P}<0.01$ vs IR group; ${ }^{\psi} \psi \mathrm{P}<0.01$ vs IR group for $4 \mathrm{~h}$.

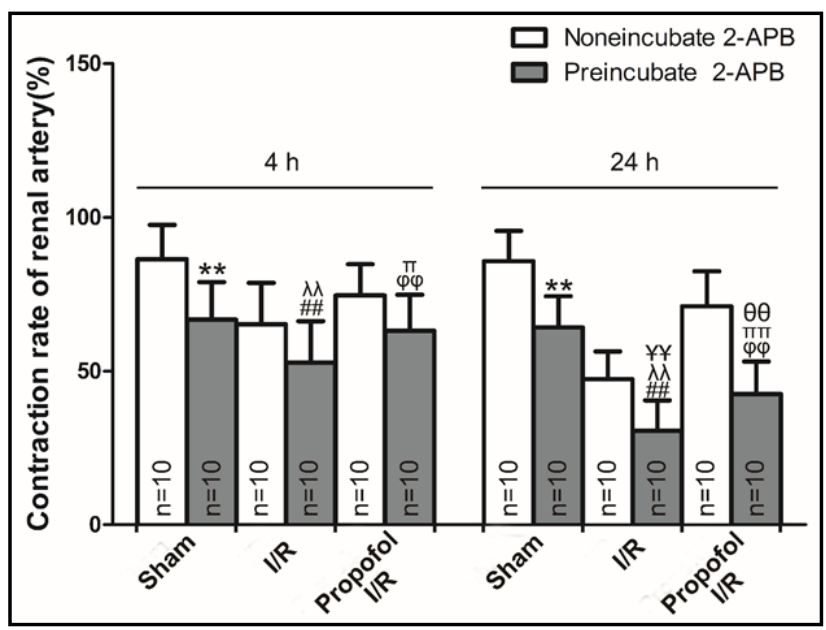

Fig. 6. The rate of change of the vascular contraction amplitude of the renal interlobar artery in different groups in response to high $\mathrm{KCl}$ without and with 2 -APB. ${ }^{* *} \mathrm{P}<0.01$ vs sham group; ${ }^{\# \#} \mathrm{P}<0.01$ vs IR group; ${ }^{\psi \psi} \mathrm{P}<0.01$ vs IR group; ${ }^{\lambda} \mathrm{P}<0.05$ or ${ }^{\lambda \lambda} \mathrm{P}<0.01$ vs sham group of the same reperfusion time with 2 -APB; ${ }^{\pi} \mathrm{P}<0.05$ or ${ }^{\pi \pi} \mathrm{P}<0.01$ vs IR group of the same reperfusion time with $2-\mathrm{APB} ;{ }^{¥} \mathrm{P}<0.01$ vs IR group with $4 \mathrm{~h}$ of reperfusion and $2-\mathrm{APB} ;{ }^{\theta} \mathrm{P}<0.01$ vs propofol+IR group with 4 $\mathrm{h}$ of reperfusion $2-\mathrm{APB}$. 


\section{Kidney \\ Blood Pressure Research}

Kidney Blood Press Res 2018;43:1607-1622

\begin{tabular}{l|l}
\hline DOI: 10.1159/000494450 & (c) 2018 The Author(s). Published by S. Karger AG, Base
\end{tabular}
Fig. 7. Changes in the vascular systolic velocity of the renal interlobar artery in different groups induced by high $\mathrm{KCl}$ without and with 2 -APB. ${ }^{* *} \mathrm{P}<0.01$ vs sham group; ${ }^{\# \#} \mathrm{P}<0.01$ vs IR group; ${ }^{\psi} \psi \mathrm{P}<0.01$ vs IR group; ${ }^{\lambda \lambda} \mathrm{P}<0.01$ vs sham group of the same ischemia-reperfusion time with 2-APB; ${ }_{\pi \pi} \mathrm{P}<0.01$ vs IR group of the same ischemiareperfusion time with $2-\mathrm{APB}$; ${ }^{¥} \mathrm{P}<0.01$ vs IR group with $4 \mathrm{~h}$ of reperfusion followed by 2 -APB; ${ }^{\theta \theta} \mathrm{P}<0.01$ vs propofol+IR group with $4 \mathrm{~h}$ of reperfusion followed by 2 -APB.

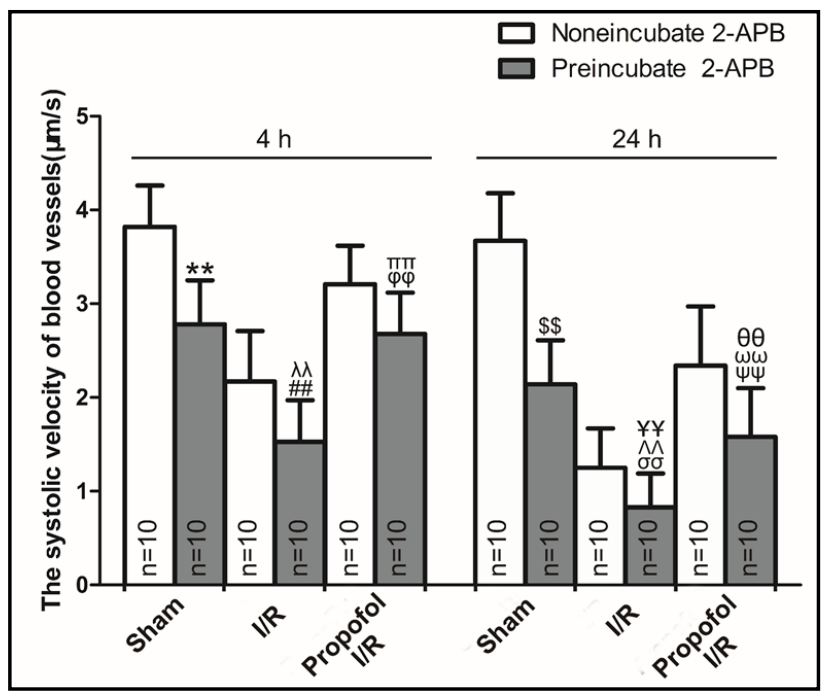

shrinkage rate of the propofol+IR group treated with high $\mathrm{KCl}$ increased in comparison with that of the IR group, and the difference was statistically significant at $4 \mathrm{~h}(\mathrm{n}=10, \mathrm{P}<0.05)$ and $24 \mathrm{~h}(\mathrm{n}=10, \mathrm{P}<0.01)$; the renal interlobar artery shrinkage rates of the IR and propofol+IR groups were lower after $24 \mathrm{~h}$ of reperfusion than after $4 \mathrm{~h}$, and the difference was statistically significant ( $\mathrm{n}=10, \mathrm{P}<0.01$ ) (Fig. 2).

Without 2-APB application, the systolic velocities of blood vessels in the sham, IR and propofol+IR groups after $4 \mathrm{~h}$ of reperfusion were $3.82 \pm 0.44 \mu \mathrm{m} / \mathrm{s}(\mathrm{n}=10), 2.17 \pm 0.54 \mu \mathrm{m} / \mathrm{s}$ $(\mathrm{n}=10)$ and $3.21 \pm 0.41 \mu \mathrm{m} / \mathrm{s}(\mathrm{n}=10)$, respectively, after the rat renal interlobar artery was treated with $\mathrm{KCl}(60 \mathrm{mmol} / \mathrm{L})$. The systolic velocities of blood vessels in the experimental groups (sham, IR and Pro groups) after $24 \mathrm{~h}$ of reperfusion were $3.67 \pm 0.51 \mu \mathrm{m} / \mathrm{s}(\mathrm{n}=10)$, $1.25 \pm 0.42 \mu \mathrm{m} / \mathrm{s}(\mathrm{n}=10)$ and $2.34 \pm 0.63 \mu \mathrm{m} / \mathrm{s}(\mathrm{n}=10)$, respectively. The systolic velocity of blood vessels in the sham, IR and Pro groups at $4 \mathrm{~h}$ of reperfusion were $2.14 \pm 0.47 \mu \mathrm{m} / \mathrm{s}$ $(\mathrm{n}=10), 0.83 \pm 0.36 \mu \mathrm{m} / \mathrm{s}(\mathrm{n}=10)$ and $1.58 \pm 0.52 \mu \mathrm{m} / \mathrm{s}(\mathrm{n}=10)$, respectively, with application of 2-APB (100 mmol/L),. Finally, the systolic velocities of blood vessels in the experimental groups (sham, IR and Pro group) for $24 \mathrm{~h}$ of reperfusion were $2.78 \pm 0.47 \mu \mathrm{m} / \mathrm{s}(\mathrm{n}=10)$, $1.53 \pm 0.44 \mu \mathrm{m} / \mathrm{s}(\mathrm{n}=10)$ and $2.68 \pm 0.43 \mu \mathrm{m} / \mathrm{s}(\mathrm{n}=10)$, respectively.

The systolic velocity of blood vessels of each group was lower after incubation with 2-APB $(100 \mathrm{mmol} / \mathrm{L})$ than without 2 -APB incubation, and the results were statistically significant $(\mathrm{n}=10, \mathrm{P}<0.01)$ (Fig. 7). After incubation with 2-APB $(100 \mathrm{mmol} / \mathrm{L})$, the systolic velocity of blood vessels of the IR group treated with high $\mathrm{KCl}$ decreased in comparison with that of the sham group blood vessels, and the difference was statistically significant at $4 \mathrm{~h}(\mathrm{n}=10$, $\mathrm{P}<0.01)$ and $24 \mathrm{~h}(\mathrm{n}=10, \mathrm{P}<0.01)$; the systolic velocity of blood vessels of the propofol+IR group treated with high $\mathrm{KCl}$ increased compared with the vessels of the IR group, and the difference was statistically significant at $4 \mathrm{~h}(\mathrm{n}=10, \mathrm{P}<0.01)$ and $24 \mathrm{~h}(\mathrm{n}=10, \mathrm{P}<0.01)$; the systolic velocities of blood vessels of the IR and propofol+IR groups at $24 \mathrm{~h}$ treated with high $\mathrm{KCl}$ decreased compared with those of the IR and propofol+IR groups at $4 \mathrm{~h}(\mathrm{n}=10, \mathrm{P}<0.01)$ (Fig. 7).

The effect of Gap27 on the amplitude and velocity of renal interlobar artery constriction induced by high $\mathrm{KCl}$ in each group

2-APB is a compound that interferes with many pathways (through $\mathrm{IP}_{3}$ receptors, TRP channels); thus, Gap27 was also selected as a gapjunction 43 blocker. The shrinkage rate of each group was lower after incubation with Gap27 (100 mmol/L), than without Gap27 treatment, as shown in Fig. 8E, and the results were statistically significant $(n=6, p<0.01)$. After incubation with Gap $27(100 \mathrm{mmol} / \mathrm{L})$, therenal interlobararteryshrinkage rate of the IRgrouptreated with high $\mathrm{KCl}$ decreased compared with that of the sham group, and the difference was statistically 


\section{Kidney Blood Pressure Research}

Fig. 8. The rate of change of vascular contraction amplitude and the vascular systolic velocity of the renal interlobar artery in different groups exposed to high $\mathrm{KCl}$ without and with Gap27. A: control group; B: sham group; C: IR group; D: propofol+IR group. E: vascular contraction rate. ${ }^{* *} \mathrm{p}<0.01$ versus Sham group. $\#$ \# $<0.01$ preincubated with Gap27 versus not preincubated with Gap27. \&\& $p<0.01 \quad$ propofol+IR group versus IR group. F: vessel contraction rate. ${ }^{* *} \mathrm{p}<0.05$ preincubated with Gap27 versus not preincubated with Gap27. ${ }^{\# \#} \mathrm{p}<0.05$ IR group versus sham group. $\quad{ }^{\&} \mathrm{p}<0.05$ propofol+IR group versus IR group.

significant at $24 \mathrm{~h}$ $(\mathrm{n}=6, \mathrm{P}<0.01)$; the renal interlobar artery shrinkage rate of the propofol+IR group treated with high $\mathrm{KCl}$ increased compared with that of the IR group, and the difference was statistically significant at $24 \mathrm{~h}$ $(\mathrm{n}=6, \mathrm{P}<0.01) ;$ the renal interlobar artery shrinkage rates of the IR and propofol+IR $24 \quad \mathrm{~h}$ groups treated with high KCl decreased, and the difference was statistically significant $\quad(n=10$, $\mathrm{P}<0.01$ ) (Fig. 8E).

The systolic velocity of blood vessels from each
Chang et al.: The Protective Effect of Propofol Against Ischemia-Reperfusion Injury in the Interlobar Arteries

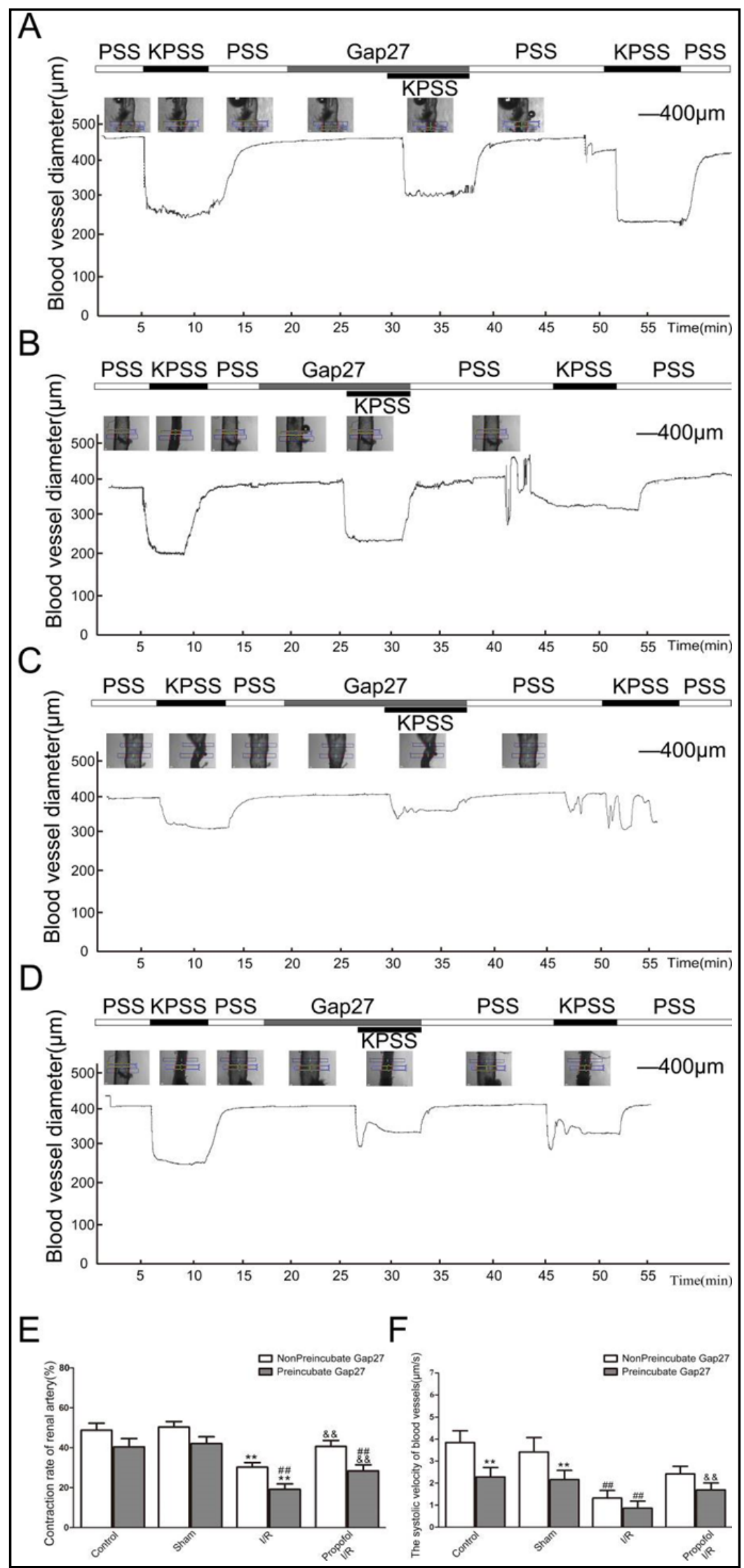




\section{Kidney \\ Blood Pressure Research}

Kidney Blood Press Res 2018;43:1607-1622

\begin{tabular}{l|l}
\hline DOI: $10.1159 / 000494450$ & (c) 2018 The Author(s). Published by S. Karger AG, Basel
\end{tabular}

group after incubation with Gap27 $(100 \mathrm{mmol} / \mathrm{L})$, was lower than that of the vessels without Gap27, as shown in Fig. 8F, and the results were statistically significant $(n=6$, $\mathrm{p}<0.01$ ). After incubation with Gap27 (100 mmol/L), the systolic velocity of blood vessels of the IR group treated with high $\mathrm{KCl}$ decreased compared with that of the sham group vessels, and the difference was statistically significant at $24 \mathrm{~h}(\mathrm{n}=6, \mathrm{P}<0.01)$; the systolic velocity of blood vessels of the propofol+IR group treated with high $\mathrm{KCl}$ increased compared with that of the IR group, and the difference was statistically significant at $24 \mathrm{~h}(\mathrm{n}=6, \mathrm{P}<0.01)$; the systolic velocity of blood vessels of the IR and propofol+IR $24 \mathrm{~h}$ groups treated with high $\mathrm{KCl}$ decreased, and the difference was statistically significant $(n=6, P<0.01)$

The expression of Cx43 protein in the renal interlobar artery of each group

As the western blot results

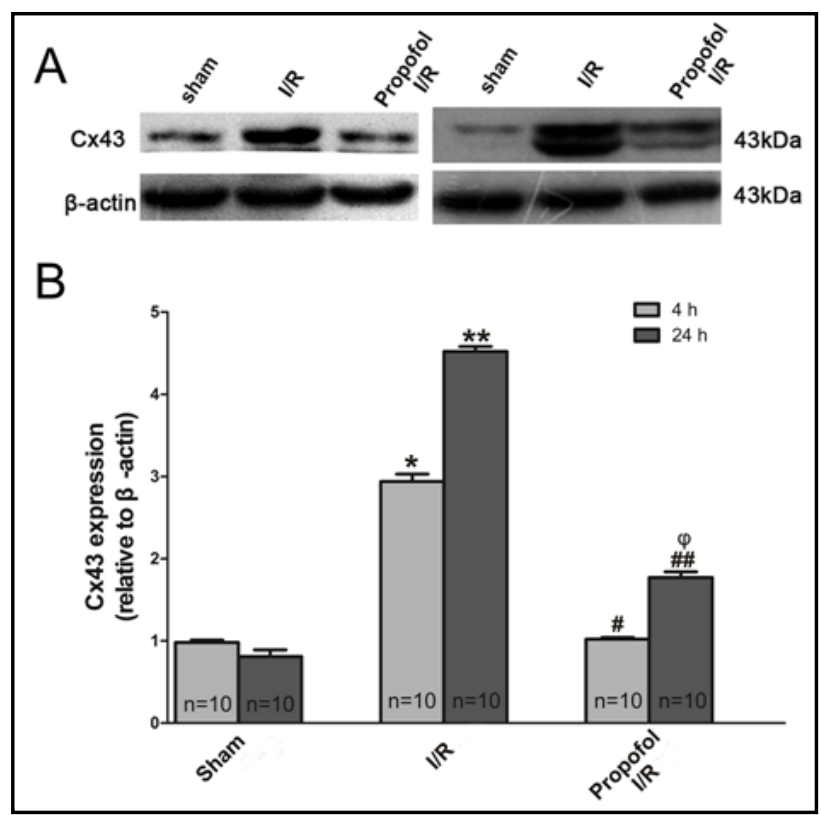

Fig. 9. The change in the expression of $\mathrm{Cx} 43$ in the renal interlobar artery of each group. A: The expression of $\mathrm{Cx} 43$ protein in the renal interlobar artery in each group after $4 \mathrm{~h}$ and $24 \mathrm{~h}$ of reperfusion. B: The differences in the expression of $\mathrm{Cx} 43$ protein in the renal interlobar artery of each group. ${ }^{*} \mathrm{P}<0.05$ or ${ }^{* *} \mathrm{P}<0.01$ vs sham group of the same ischemiareperfusion time; ${ }^{\# \#} \mathrm{P}<0.01$ or ${ }^{\# \#} \mathrm{P}<0.01$ vs IR group of the same ischemia-reperfusion time; ${ }^{\psi} \mathrm{P}<0.05$ vs IR group of the same ischemia-reperfusion time. suggested, the expression of $\mathrm{Cx} 43$ protein in the IR 4 h group increased obviously $(\mathrm{P}<0.05)$ compared with that of the sham group (Fig. 9A). No significant difference was found in Cx43 protein expression in the renal artery between the sham $4 \mathrm{~h}$ group and the propofol $4 \mathrm{~h}$ group ( $\mathrm{P}>0.05)$ (Fig. 9A). The expression of $\mathrm{Cx} 43$ protein was obviously lower in the propofol $4 \mathrm{~h}$ group $(\mathrm{P}<0.05)$ than in the IR $4 \mathrm{~h}$ group (Fig. 9A). The expression of $\mathrm{Cx} 43$ protein increased markedly $(\mathrm{P}<0.05)$ in the IR $24 \mathrm{~h}$ group and the propofol $24 \mathrm{~h}$ group compared with the sham group (Fig. 9B). The expression of $\mathrm{Cx} 43$ protein was obviously lower in the propofol 24 h group $(\mathrm{P}<0.05)$ than in the IR 24 h group (Fig. 9B).

\section{Discussion}

The experimental study confirmed that, after ischemia-reperfusion injury, 1) the BUN and $\mathrm{SCr}$ of rats markedly increased; 2) effects at the cellular level included coagulation necrosis and shedding of some cells; solidification of some nuclear chromatin; degeneration of cytoplasmic vacuoles; high renal interstitial vascular congestion; and obvious inflammatory cell infiltration, characterized by focal hemorrhages; 3 ) the contractile activity of the renal interlobar artery was obviously weakened; 4) after ischemia-reperfusion, the tension of the arteries in the renal lobe increased obviously; and 5) the expression of $\mathrm{Cx} 43$ in kidney tissues increased obviously. In addition, the damage was more severe at $24 \mathrm{~h}$ of postischemic reperfusion than at $4 \mathrm{~h}$. However, after pretreatment with propofol, whether reperfusion lasted for $4 \mathrm{~h}$ or $24 \mathrm{~h}$, the previously increased expression of Cx 43 decreased obviously, and renal damage (morphological and functional) was clearly reduced at each time point. 


\section{Kidney Blood Pressure Research}

Kidney Blood Press Res 2018;43:1607-1622

\begin{tabular}{l|l}
\hline DOI: $10.1159 / 000494450$ & (c) 2018 The Author(s). Published by S. Karger AG, Basel
\end{tabular}

Published online: 22 October 2018

www.karger.com/kbr

1619

Some studies have found that renal vascular endothelial cells undergo leukocyte adhesion and the accumulation of red blood cells and platelets in the event of renal ischemiareperfusion, which causes vascular obstruction $[27,28]$. The renal vascular endothelial cell injury was coupled with increased levels of vasoconstrictor substances, along with reduced levels of vasodilator substances and many other factors, affecting blood vessel luminal obstruction, blood flow velocity, and blood vessel elasticity decreased vasoconstriction [24]. Thus, our study found that ischemia-reperfusion resulted in increased tension in the interlobar arteries, and the initial diameter of the IR vessels was obviously smaller than that of the control group vessels (Fig. 2, 4). The contraction amplitude (Fig. 2, 5) and contraction rate (Fig. 2,6) of the IR-subjected interlobar arteries were lower than those of the control group at $4 \mathrm{~h}$ and $24 \mathrm{~h}$ (Fig. 2, 5, 6). The results suggested that the renal artery was damaged in the process of renal ischemia and reperfusion, which decreased the contraction and damaged the microcirculation. Renal function (Table 1) and corresponding morphological changes (Fig. 1 and Table 2) were reduced by microcirculation disorder in renal ischemiareperfusion. These findings are consistent with those of previous studies.

It is widely known that GJs transmit electrical and chemical signals to synchronize the electrical and mechanical activity of the vessel wall in the vertical and horizontal directions, allowing the blood vessel to function in a unified manner. In addition, GJs are critical for regulating the coordination and synchronization of vascular motion [29]. The present study applies the nonspecific gap junction blocker 2-APB and the specific blocker Gap27, and the results suggest that renal artery contraction amplitude and contraction speed can be reduced by using $100 \mathrm{mmol} / \mathrm{L}$ 2-APB or Gap27 (including $4 \mathrm{~h}$ and $24 \mathrm{~h}$ ) (Fig. 2, 7,8), and GJs may play a role in vasoconstriction induced by high $\mathrm{KCl}$. Increased free radicals, intracellular calcium overload, the opening of the mitochondrial permeability transition pores, endothelial dysfunction, the appearance of a prothrombogenic phenotype, development of capillary no-reflow, and pronounced inflammatory responses are also predominant in the development of reperfusion injury $[2,3,30]$. Many of the substances produced after ischemia-reperfusion, including free radicals and $\mathrm{Ca}^{2+}$, can be freely diffused through gaps between cells $[1,29]$. The abnormal increase in the expression of the gap junction protein Cx43 (Fig. 9) in renal tissue (including the interlobar arteries) after ischemia-reperfusion may exacerbate the proliferation of harmful substances in the cell, and it may also exacerbate damage to the reperfused tissues. Obviously, abnormal expression of the gap junction protein $\mathrm{Cx} 43$ is a double-edged sword. On the one hand, GJs contribute to the synchronicity of kidney vasomotor activity, but on the other hand, they also increase the spread of harmful substances from cell to cell. As the results of our experiment suggested, a compensatory increase in $\mathrm{Cx} 43$ expression occurred after ischemia-reperfusion but was not able to restore the vasoconstrictive activity of the renal arteries (Fig. 2, 5, 6, 8).

Propofol is a sedative drug commonly applied in anesthesiology and intensive care medicine. Recent studies have found that propofol, in addition to its routine use in anesthesia, can fulfill many other roles, such as regulating the mesenteric microcirculation [31], which improves the ventricular arrhythmia induced by ischemia [32]. It has also been found by multiple research teams that propofol has protective effects against IRI in multiple organs $[33,34]$. Propofol infusion has also been suggested to have protective effects against renal IRI in rats, but the underlying mechanism is not fully understood $[10,13,35]$. In the present study, HE staining of IRI-affected rat renal tissue (Fig. 1) and biochemical tests of intravenous blood (Table 1) have confirmed that propofol has a protective effect against renal IRI, which is consistent with what other researchers have found [35]. Although the protective mechanism of propofol against renal ischemia-reperfusion is not fully clear, there have been studies suggesting that the gap junction protein $\mathrm{Cx} 43$ may be involved in the role of propofol $[13,29$, $32,36]$. Our research also suggests that propofol can reduce abnormal increases in kidney Cx43 protein expression caused by ischemia-reperfusion (Fig. 9). On the one hand, the state of renal vascular function state may be restored, and our findings confirm that propofol improved the amplitude and velocity of renal artery contraction after ischemia-reperfusion 


\section{Kidney \\ Blood Pressure Research}

Kidney Blood Press Res 2018;43:1607-1622

\begin{tabular}{l|l}
\hline DOI: $10.1159 / 000494450$ & (c) 2018 The Author(s). Published by S. Karger AG, Basel
\end{tabular}

Published online: 22 October 2018

www.karger.com/kbr

Chang et al.: The Protective Effect of Propofol Against Ischemia-Reperfusion Injury in

the Interlobar Arteries

(Fig. 5, 6). More importantly, the expression of propofol decreased $\mathrm{Cx} 43$, which also reduced the increase in renal arterial artery tension caused by ischemia-reperfusion (Fig. 2, 4). On the other hand, the reduction of Cx43 expression by propofol can also decrease the spread of harmful substances generated by ischemia-reperfusion. Although we have revealed evidence that the reduction of $\mathrm{Cx} 43$ gap junction protein expression in the renal arteries may explain the protective effect of propofol against kidney IRI, many questions remain unanswered. What is the mechanism by which propofol reduces CX43 expression? Are the reduced levels of $\mathrm{Cx} 43$ expression driven by a decrease in unphosphorylated or phosphorylated $\mathrm{Cx} 43$ ? These problems will gradually be solved in our future research.

\section{Conclusion}

Based on the above analysis, we hypothesized that the mechanism by which propofol reduces renal IRI in rats may be associated with the inhibition of abnormal $\mathrm{Cx} 43$ protein expression in the renal artery. We also found that in the propofol $4 \mathrm{~h}$ group, propofol had a protective effect against renal IRI and could mitigate the damage to the level found in the sham-operated group (Fig. 2, 4, 5, 6, 8). However, in the propofol $24 \mathrm{~h}$ group, the results suggested that the propofol did not protect the tissue to the same degree (Fig. 2, 4, 5, 6, 8). We showed that the damage was more severe after $24 \mathrm{~h}$ of postischemic reperfusion than after only $4 \mathrm{~h}$, such that the use of protective drugs such as propofol could not restore it to the normal state. The results suggest that it is best to treat renal IRI as soon as possible. At the same time, our research may also reveal a novel mechanism by which propofol reduces ischemia-reperfusion injury, i.e., by inhibiting the abnormal expression of gap junctions. This study clarifies a novel mechanism for the action of propofol against IRI and may lead to new treatments for IRI.

\section{Acknowledgements}

This study was supported by grants from the National Basic Research Program of China (no. 2012CB52660000), the National Natural Science Foundation of China (nos. 31100829 and 81000411) and the High Level Talent Research Project of Shihezi University (grant no. RCSX201705). This research was supported by the Laboratory of Xinjiang Endemic and Ethnic Diseases. We are grateful to Professor Jun-Qiang Si and Professor Li Li for their expertise in statistical analysis.

\section{Disclosure Statement}

The authors declare no conflict of interests.

\section{References}

1 Kalogeris T, Baines CP, Krenz M, Korthuis RJ: Ischemia/reperfusion. Compr Physiol 2016;7:113-170.

$\checkmark 2$ Arumugam TV, Magnus T, Woodruff TM, Proctor LM, Shiels IA, Taylor SM: Complement mediators in ischemia-reperfusion injury. Clin Chim Acta 2006;374:33-45.

-3 Arumugam TV, Shiels IA, Woodruff TM, Granger DN, Taylor SM: The role of the complement system in ischemia-reperfusion injury. Shock 2004;21:401-409.

4 Lowenstein CJ: Myocardial reperfusion injury. N Engl J Med 2007;357:2409-2410.

5 Goodenough DA, Paul DL: Gap junctions. Csh Perspect Biol 2009;1:a002576. 


\section{Kidney \\ Blood Pressure Research}

Kidney Blood Press Res 2018;43:1607-1622

\begin{tabular}{l|l}
\hline DOI: $10.1159 / 000494450$ & (c) 2018 The Author(s). Published by S. Karger AG, Basel
\end{tabular}

Published online: 22 October 2018

www.karger.com/kbr

1621

-6 Hwan SK, Beyer EC: Heterogeneous localization of connexin40 in the renal vasculature. Microvasc Res 2000;59:140-148.

7 Brisset AC, Isakson BE, Kwak BR: Connexins in vascular physiology and pathology. Antioxid Redox Signal 2009;11:267-282.

-8 Pecoraro M, Verrilli V, Pinto A, Popolo A: Role of connexin 43 in cardiovascular diseases. Eur J Pharmacol 2015;768:71-76.

9 Ge M, Luo G, Yao W, Luo C, Zhou S, Yuan D, Chi X, Hei Z: Propofol pretreatment attenuates remote kidney injury induced by orthotopic liver autotransplantation, which is correlated with the activation of nrf2 in rats. Mol Med Rep 2015;11:3962-3968.

-10 Zhang Y, Chen Z, Feng N, Tang J, Zhao X, Liu C, Xu H, Zhang M: Protective effect of propofol preconditioning on ischemia-reperfusion injury in human hepatocyte. J Thorac Dis 2017;9:702-710.

11 Yang XL, Wang D, Zhang GY, Guo XL: Comparison of the myocardial protective effect of sevoflurane versus propofol in patients undergoing heart valve replacement surgery with cardiopulmonary bypass. BMC Anesthesiol 2017;17:37.

12 Calzetta L, Soggiu A, Roncada P, Bonizzi L, Pistocchini E, Urbani A, Rinaldi B, Matera MG: Propofol protects against opioid-induced hyperresponsiveness of airway smooth muscle in a horse model of targetcontrolled infusion anaesthesia. Eur J Pharmacol 2015;765:463-471.

13 Yang S, Wei-Ping C, Ling P: Effects of propofol on renal ischemia/reperfusion injury in rats. Exp Ther Med 2013;6:1177-1183.

14 Assad AR, Delou JM, Fonseca LM, Villela NR, Nascimento JH, Verçosa N, Lopes AG, Capella MA: The role of katp channels on propofol preconditioning in a cellular model of renal ischemia-reperfusion. Anesth Analg 2009;109:1486-1492.

15 Eroglu A: The effect of intravenous anesthetics on ischemia-reperfusion injury. Biomed Res Int 2014;2014:821513.

16 Wang HH, Zhou HY, Chen CC, Zhang XL, Cheng G: Propofol attenuation of renal ischemia/reperfusion injury involves heme oxygenase-1. Acta Pharmacol Sin 2007;28:1175-1180.

17 Mi LY, Woo SJ, Ho LE, Youngjin M, Joo SY, Yeon KJ, Uk KJ: Protective effects of propofol against hydrogen peroxide-induced oxidative stress in human kidney proximal tubular cells. Korean J Anesthesiol 2012;63:441-446.

18 Ye L, Luo CZ, Mccluskey SA, Pang QY, Zhu T: Propofol attenuates hepatic ischemia/reperfusion injury in an in vivo rabbit model. J Surg Res 2012;178:65-70.

19 National Research Council of the National Academies: Guide for the care and use of laboratory animals, ed 8, revised.. Washington DC, the National Academies Press, 2011, pp 11-13.

20 Inagawa G, Sato K, Kikuchi T, Nishihama M, Shioda M, Koyama Y, Yamada Y, Andoh T: Chronic ethanol consumption does not affect action of propofol on rat hippocampal acetylcholine release in vivo. Br J Anaesth 2004;93:737-739.

-21 Liu KX, Rinne T, He W, Wang F, Xia Z: Propofol attenuates intestinal mucosa injury induced by intestinal ischemia-reperfusion in the rat. J Anaesth 2007;54:366-374.

22 Ji W, Wang WM, Chang YC, Wang Y, Zhang L, Ma KT, Si JQ, Li L, Li YL: Effects of estrogen on the vasomotor function of rats' renal interlobar arteries and cx43 expression after renal ischemia-reperfusion injury. Journal of Xi'an Jiaotong University (Medical Sciences) 2017;38:479-486

23 Li L, Zhang W, Shi WY, Ma KT, Zhao L, Wang Y, Zhang L, Li XZ, Zhu H, Zhang ZS: The enhancement of Cx45 expression and function in renal interlobar artery of spontaneously hypertensive rats at different age. Kidney Blood Press Res 2015;40:52-65.

24 Li L, Wang R, Ma KT, Li XZ, Zhang CL, Liu WD, Zhao L, Si JQ: Differential effect of calcium-activated potassium and chloride channels on rat basilar artery vasomotion. J Huazhong Univ Sci Technolog Med Sci 2014;34:482-490.

25 Shen X, Hu B, Xu G, Chen F, Ma R, Zhang N, Liu J, Ma X, Zhu J, Wu Y: Activation of nrf2/ho-1 pathway by glycogen synthase kinase- $3 \beta$ inhibition attenuates renal ischemia/reperfusion injury in diabetic rats. Kidney Blood Press Res 2017;42:369-378.

26 Paller MS, Hoidal JR, Ferris TF: Oxygen free radicals in ischemic acute renal failure in the rat. J Clin Invest 1984;74:1156-1164. 


\section{Kidney \\ Blood Pressure Research}

Kidney Blood Press Res 2018;43:1607-1622

\begin{tabular}{l|l}
\hline DOI: $10.1159 / 000494450$ & (c) 2018 The Author(s). Published by S. Karger AG, Base
\end{tabular}

Published online: 22 October 2018

www.karger.com/kbr

1622

Chang et al.: The Protective Effect of Propofol Against Ischemia-Reperfusion Injury in

the Interlobar Arteries

27 Singbartl K, Forlow SB, Ley K: Platelet, but not endothelial, p-selectin is critical for neutrophil-mediated acute postischemic renal failure. FASEB J 2001;15:2337-2344.

28 Kosaka H, Yoneyama H, Zhang L, Fujii S, Yamamoto A, Igarashi J: Induction of lox-1 and inos expressions by ischemia-reperfusion of rat kidney and the opposing effect of l-arginine. FASEB J 2003;17:636-643.

-29 Johnstone S, Isakson B, Locke D: Biological and biophysical properties of vascular connexin channels. Int Rev Cell Mol Biol 2009;278:69-118.

-30 Hausenloy DJ, Yellon DM: Myocardial ischemia-reperfusion injury: A neglected therapeutic target. J Clin Invest 2013;123:92-100.

-31 Wan HJ, Wang Y, Si JQ, Li L: Propofol induced vasodilation of mesenteric arterioles via BKCa channel and gap junction. Experimental and Therapeutic Medicine 2018;16:2960-2968.

32 Hirata N, Kanaya N, Kamada N, Kimura S, Namiki A: Differential effects of propofol and sevoflurane on ischemia-induced ventricular arrhythmias and phosphorylated connexin 43 protein in rats. Anesthesiology 2009;110:50-57.

-33 Kato R, Foëx P: Myocardial protection by anesthetic agents against ischemia-reperfusion injury: An update for anesthesiologists. Can J Anaesth 2002;49:777-791.

34 Chen L, Gong Q, Xiao C: Effects of propofol, midazolam and thiopental sodium on outcome and amino acids accumulation in focal cerebral ischemia-reperfusion in rats. Chin Med J 2003;116:292-296.

-35 Eroglu T, Bozkurt M, Kapi E, Selcuk CT, Kuvat SV, Tufek A, Isik FB, Bozarslan BH, Firat U, Satici O: A study on the effects of the use of propofol in experimental model inferior epigastric island flap on ischemiareperfusion injury. J Craniofac Surg 2017;28:2193-2198.

-36 Schulz R, Görge PM, Görbe A, Ferdinandy P, Lampe PD, Leybaert L: Connexin 43 is an emerging therapeutic target in ischemia/reperfusion injury, cardioprotection and neuroprotection. Pharmacol Ther 2015;153:90-106. 